\title{
Partial Purification and Characterization of Glucose-6-phosphate Isomerase from Dictyostelium discoideum
}

\author{
By DAVID A. THOMAS \\ Department of Developmental Biology, Boston Biomedical Research Institute, \\ 20 Staniford Street, Boston, Massachusetts 02114, U.S.A.
}

(Received 4 August 1980; revised 19 February 1981)

\begin{abstract}
Glucose-6-phosphate isomerase was partially purified from cells of Dictyostelium discoideum in the culmination stage of development. The enzyme had a $\mathrm{pH}$ optimum of about 8.5 in Tris/ $\mathrm{HCl}$ buffer. Activity was not inhibited by $p$-chloromercuribenzoate or iodoacetate. The enzyme exhibited Michaelis-Menten kinetics and the $K_{\mathrm{m}}$ values for glucose 6-phosphate and fructose 6-phosphate were $2 \mathrm{mM}$ and $0.1 \mathrm{mM}$, respectively. Erythrose 4-phosphate was a strong competitive inhibitor of the enzyme with a $K_{1}$ value of $3.8 \mu \mathrm{M}$, whereas 6-phosphogluconate was less effective with a $K_{\mathrm{i}}$ of $0.1 \mathrm{mM}$.
\end{abstract}

\section{INTRODUCTION}

A recent report from this laboratory indicated that Dictyostelium discoideum contains all the enzymes necessary for both oxidative and non-oxidative pentose phosphate metabolism during development (Thomas, 1979). One of these enzymes, glucose-6-phosphate isomerase (D-glucose-6-phosphate ketol-isomerase; EC 5.3.1.9), may play a role in regulating the activity of these two branches of metabolism. The isomerase is responsible for catalysing the interconversion of glucose 6-phosphate and fructose 6-phosphate. During development of $D$. discoideum the concentrations of these two sugar phosphates increase approximately threefold between the aggregation and culmination stages, whereas isomerase activity remains relatively constant (Thomas, 1979; Cleland \& Coe, 1968). Several groups of workers (Salas et al., 1965; Zalitis \& Oliver, 1967; Grazi et al., 1960; Venkataraman \& Racker, 1961) have demonstrated that the isomerases isolated from plant and animal sources are sensitive to inhibition by specific pentose phosphate intermediates. Based on these inhibitor studies, some authors (Grazi et al., 1960; Parr, 1956; Stadtman, 1966) have suggested that glucose6-phosphate isomerase may be an important regulatory enzyme involved in the control of carbohydrate metabolism. Although hexose metabolism has been extensively studied during development in $D$. discoideum, little information is available concerning the properties of the isomerase in this organism.

This paper reports the partial purification and kinetic characterization of glucose6-phosphate isomerase from $D$. discoideum.

\section{METHODS}

Chemicals. Bovine serum albumin, NAD, NADP, streptomycin sulphate, resorcinol, and glucose-6-phosphate dehydrogenase (EC 1.1.1.49; yeast enzyme) were obtained from Sigma. All other chemicals used were reagent grade.

Growth conditions. Dictyostelium discoideum strain NC-4 (ATCC 24697) was grown with Escherichia coli on nutrient agar sheets as previously described (Marshall et al., 1970). Amoebae were harvested, washed free of bacteria, and spread on $2 \%(\mathrm{w} / \mathrm{v})$ agar sheets $(38 \times 25 \mathrm{~cm})$ containing $10 \mathrm{~mm}$-phosphate buffer pH 6.5 and $1 \mathrm{mM}$-EDTA. The agar sheets were incubated at 15 or $22^{\circ} \mathrm{C}$. 
Enzyme assay. Enzyme activity in the direction of glucose 6-phosphate formation was measured using the coupled enzyme system of Noltmann (1966). The standard reaction mixture contained (total volume $1.0 \mathrm{ml}$ ): $100 \mu \mathrm{mol}$ Tricine/KOH buffer $\mathrm{pH} 7 \cdot 6,2 \mu \mathrm{mol} \mathrm{MgCl}_{2}, 1 \mu \mathrm{mol} \mathrm{NADP}^{+}, 5 \mu \mathrm{mol}$ fructose 6-phosphate, 2 units glucose-6-phosphate dehydrogenase and enzyme. Enzyme activity was followed by monitoring the increase in absorbance at $340 \mathrm{~nm}$, at about $23^{\circ} \mathrm{C}$.

Glucose-6-phosphate isomerase activity was also measured in the direction of fructose 6-phosphate formation using the colorimetric technique of Roe \& Papadopoulos (1954). The reaction mixture contained (total volume 1.0

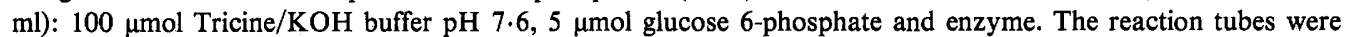
incubated at $25^{\circ} \mathrm{C}$ and the reaction was terminated after $10 \mathrm{~min}$ by the addition of Roe's reagent [ $3 \mathrm{ml} \mathrm{conc.} \mathrm{HCl}$ plus $1.0 \mathrm{ml} 1 \%(\mathrm{w} / \mathrm{v})$ resorcinol in $95 \%(\mathrm{v} / \mathrm{v})$ ethanol]. The colour was developed by heating the mixture at $80^{\circ} \mathrm{C}$ for $10 \mathrm{~min}$. After rapid cooling to room temperature the absorbance of the solution was measured at $530 \mathrm{~nm}$.

One unit of activity is defined as the amount of enzyme catalysing the formation of $1 \mu \mathrm{mol}$ product $\min ^{-1}$ under the assay conditions. Specific activity is expressed as units (mg protein) ${ }^{-1}$. Protein was determined by Lowry's method, using bovine serum albumin as the standard.

Purification of glucose-6-phosphate isomerase. Enzyme was purified from cells in the culmination stage of development. Vegetative amoebae were harvested, washed free of bacteria and replated on non-nutrient agar (Marshall et al., 1970). Cells were allowed to differentiate at $22^{\circ} \mathrm{C}$ until they reached the culmination stage of development $(18$ to $20 \mathrm{~h}$ ). The cells were washed off the agar with cold $50 \mathrm{mM}$-Tris/ $\mathrm{HCl}$ buffer $\mathrm{pH} 7 \cdot 5$. The cell suspension was stored frozen at $-20^{\circ} \mathrm{C}$. After thawing at room temperature, suspensions were passed through a Yeda press at $17.5 \mathrm{MPa}$. The supernatant fraction (crude extract) after centrifugation at $27000 \mathrm{~g}$ for $20 \mathrm{~min}$ at $4{ }^{\circ} \mathrm{C}$ contained all of the isomerase activity. The crude extract was treated with streptomycin sulphate to a final concentration of $5 \%(\mathrm{w} / \mathrm{v})$ and stirred at $4{ }^{\circ} \mathrm{C}$ for $1 \mathrm{~h}$, then centrifuged at $27000 \mathrm{~g}$ for $20 \mathrm{~min}$. This procedure removed $95 \%$ of the nucleic acids. The fraction of the supernatant precipitating between 70 and $80 \%\left(\mathrm{NH}_{4}\right)_{2} \mathrm{SO}_{4}$ saturation was collected, dissolved in $50 \mathrm{~mm}$-Tris $/ \mathrm{HCl}$ buffer $\mathrm{pH} 7.5$ and dialysed at $5{ }^{\circ} \mathrm{C}$ overnight against 100 vol. of the same buffer. A slurry of alumina $\mathrm{C} \gamma$ gel was added to the dialysed $\left(\mathrm{NH}_{4}\right)_{2} \mathrm{SO}_{4}$ fraction until all of the isomerase was absorbed. The gel containing the absorbed enzyme was collected after centrifugation for $5 \mathrm{~min}$ at $3000 \mathrm{~g}$. After washing the gel with $50 \mathrm{~mm}$-Tris $/ \mathrm{HCl}$ buffer $\mathrm{pH} 7 \cdot 5$, the isomerase was eluted by two successive extractions with 5 vol. of $0.5 \mathrm{M}-\left(\mathrm{NH}_{4}\right)_{2} \mathrm{SO}_{4}$ in $50 \mathrm{mM}$-Tris $/ \mathrm{HCl}$ buffer $\mathrm{pH} 7.5$. The enzyme was precipitated by addition of $\left(\mathrm{NH}_{4}\right)_{2} \mathrm{SO}_{4}$ to $80 \%$ saturation. After centrifugation at $27000 \mathrm{~g}$ for $20 \mathrm{~min}$ the enzyme was dissolved in $2.0 \mathrm{ml} 50 \mathrm{~mm}$-Tris/ $\mathrm{HCl}$ buffer $\mathrm{pH} 7.5$ and dialysed overnight against 100 vol. of the same buffer. The partially purified isomerase preparation was stored at $5{ }^{\circ} \mathrm{C}$. Table 1 gives a summary of the purification procedure.

\section{RES ULTS}

The purpose of this investigation was to obtain an isomerase preparation essentially free of interfering enzyme activities in order to determine the relevant kinetic constants. The partially purified isomerase fraction from step 4 (Table 1) was tested for several enzymes of hexose and pentose phosphate metabolism and found to contain low levels of glucose-6-phosphate dehydrogenase activity $(0.25 \%$ of the isomerase activity). No transketolase, transaldolase, phosphofructokinase or 6-phosphogluconate dehydrogenase activities were detected. The preparation did contain measurable levels of ribose-5-phosphate isomerase $(11 \%)$ and ribulose-5-phosphate epimerase (6\%) activity.

The purified isomerase from $D$. discoideum was stable to overnight dialysis $\left(5^{\circ} \mathrm{C}\right)$ against $50 \mathrm{mM}$-Tris/ $\mathrm{HCl}$ buffer $\mathrm{pH} 7.5$ and was also relatively stable during storage at $5^{\circ} \mathrm{C}(6 \%$ loss in activity in $7 \mathrm{~d}$ ). Incubation of the enzyme preparation at $37^{\circ} \mathrm{C}$ in $100 \mathrm{~mm}$-Tris $/ \mathrm{HCl}$ buffers at $\mathrm{pH}$ values below 7.0 resulted in a rapid loss of activity. Maximal stability was obtained at approximately $\mathrm{pH} 7.2$ under these conditions.

The activity of the purified enzyme was determined over the $\mathrm{pH}$ range 7.2 to 9.0 using two buffer systems: Tris $/ \mathrm{HCl}$ and Tricine $/ \mathrm{NaOH}$. The isomerase had a broad $\mathrm{pH}$ activity range with a maximum at $\mathrm{pH} 8.5$ in Tris/ $\mathrm{HCl}$ buffer. In Tricine/ $\mathrm{NaOH}$ buffer the enzyme activity was slightly lower.

The purified isomerase showed Michaelis-Menten kinetics when assayed at five concentrations of either substrate $(0.5,1,2,5$ and $10 \mathrm{mM}$ for glucose 6-phosphate; $0.05,0.1$, $0.2,0.5$ and $1 \mathrm{~mm}$ for fructose 6-phosphate). The apparent Michaelis constants $\left(K_{\mathrm{m}}\right)$ for glucose 6-phosphate and fructose 6-phosphate were approximately $2 \mathrm{mM}$ and $0.1 \mathrm{mM}$, respectively. The isomerase from $D$. discoideum appears to exhibit a high degree of substrate 
Table 1. Partial purification of glucose-6-phosphate isomerase from D. discoideum

\begin{tabular}{lccccc}
\multicolumn{1}{c}{ Fraction } & $\begin{array}{c}\text { Volume } \\
(\mathrm{ml})\end{array}$ & $\begin{array}{c}\text { Protein } \\
\left(\mathrm{mg} \mathrm{ml}^{-1}\right)\end{array}$ & $\begin{array}{c}\text { Total } \\
\text { activity } \\
\text { (units) }\end{array}$ & $\begin{array}{c}\text { Specific } \\
\text { activity } \\
\text { [units (mg } \\
\text { protein) }\end{array}$ & $\begin{array}{c}\text { Purification } \\
\text { factor }\end{array}$ \\
$\begin{array}{l}\text { 1. Crude extract } \\
\text { 2. Streptomycin sulphate supernatant }\end{array}$ & 50 & 19.2 & 181 & 0.188 & - \\
3. Ammonium sulphate & 47 & 8.9 & 126 & 0.302 & 1.6 \\
$\quad 70-80 \%$ pellet & 11 & 4.6 & 82.9 & 1.64 & 8.7 \\
4. Alumina C $\gamma$ gel concentrate & 2.7 & 1.1 & 42.2 & 14.2 & 75.5
\end{tabular}

Table 2. Inhibition of glucose-6-phosphate isomerase from $D$. discoideum

\begin{tabular}{llc}
\multicolumn{1}{c}{ Inhibitor } & $\begin{array}{c}\text { Concn } \\
(\mathrm{mM})\end{array}$ & $\begin{array}{c}\text { Percentage } \\
\text { inhibition* }\end{array}$ \\
Ribose 5-phosphate & 1.0 & 12 \\
Fructose 1,6-bisphosphate & 1.0 & 4 \\
Xylulose 5-phosphate & 0.5 & 1 \\
Fructose 1-phosphate & 1.0 & 10 \\
Ribulose 5-phosphate & 0.5 & 48 \\
Sedoheptulose 7-phosphate & 1.0 & 10 \\
Erythrose 4-phosphate & 0.02 & 58 \\
Glucose 1-phosphate & $1 \cdot 0$ & 0 \\
6-Phosphogluconate & $0 \cdot 2$ & 52 \\
ATP & 1.0 & 1 \\
UDPglucose & $0 \cdot 1$ & 0 \\
Phosphate & 1.0 & 0 \\
p-Chloromercuribenzoate & $0 \cdot 1$ & 2 \\
Iodoacetate & 0.1 & 0
\end{tabular}

\footnotetext{
* The glucose-6-phosphate isomerase assay was performed in both directions; the percentage inhibition was similar in both directions for each inhibitor.
}

specificity as other sugar phosphates such as ribose 5-phosphate, ribulose 5-phosphate and xylulose 5-phosphate were inactive as substrates. Substrate activity was measured using the pentose phosphate assay of Cooper et al. (1958).

The partially purified $D$. discoideum isomerase was tested for inhibition by a number of sugar phosphates (Table 2). Inhibition of the isomerase was similar in the forward and backward reactions. Of those phosphorylated compounds tested only three caused significant inhibition. Erythrose 4-phosphate was a competitive inhibitor in the presence of either substrate. An apparent $K_{1}$ value of $3.8 \mu \mathrm{M}$ was obtained using enzyme assays in the direction of glucose 6-phosphate formation at three concentrations of fructose 6-phosphate $(1 \cdot 0,0.5$ and $0.2 \mathrm{~mm}$ ) and erythrose 4-phosphate concentrations from 0 to $0.1 \mathrm{~mm}$. In control experiments it was demonstrated that erythrose 4-phosphate did not affect the activity of the coupling enzyme, glucose-6-phosphate dehydrogenase. 6-Phosphogluconate and ribulose 5-phosphate were also inhibitors of the $D$. discoideum isomerase; however, somewhat higher concentrations were needed to obtain the same degree of inhibition (Table 2). Only 6-phosphogluconate inhibition was studied in detail, and it was found to be a competitive inhibitor of both substrates, with an apparent $K_{1}$ of $0.1 \mathrm{mM}$. Enzyme assays in the direction of glucose 6-phosphate formation were performed with 0.5 and $0.2 \mathrm{~mm}$-fructose 6-phosphate. The concentrations of 6-phosphogluconate were from 0 to $2.0 \mathrm{mM}$. When the isomerase was assayed at a lower $\mathrm{pH}(7 \cdot 0)$, about $20 \%$ less inhibition was observed for the same concentration of 6-phosphogluconate. The $D$. discoideum enzyme does not appear to be sensitive to inhibition by sedoheptulose 7-phosphate and in this respect is different from two mammalian isomerases (Salas et al., 1965; Venkataraman \& Racker, 1961). 
The enzyme was not inactivated when assayed in the presence of the thiol reagents, $p$-chloromercuribenzoate and iodoacetate (Table 2).

\section{DISCUS SION}

Glucose-6-phosphate isomerase has previously been characterized in a wide variety of organisms, including mammals (Salas et al., 1965; Venkataraman \& Racker, 1961; Noltmann, 1966), plants (Takeda et al., 1967), insects (Saunders et al., 1969) and microorganisms (Klungsoyr \& Endersen, 1964; Matsushima \& Simpson, 1965). In general, the properties of the $D$. discoideum enzyme appear to be similar to those noted for isomerases isolated from other sources. The enzyme has a broad $\mathrm{pH}$ range with optimum activity at $\mathrm{pH}$ 8.5. The enzyme exhibited Michaelis-Menten kinetics with kinetic constants comparable to those of other isomerases. The enzyme was competitively inhibited by erythrose 4-phosphate and 6-phosphogluconate. However, several other phosphorylated intermediates (fructose 1-phosphate, fructose 1,6-bisphosphate, ribose 5-phosphate, xylulose 5-phosphate, sedoheptulose 7-phosphate, ATP and phosphate) which were found to inhibit yeast (Salas et al., 1965 ) and rabbit muscle (Zalitis \& Oliver, 1967) isomerases had little effect on the activity of the $D$. discoideum enzyme (Table 2).

The intracellular concentration of 6-phosphogluconate reaches a maximum of about 0.018 mM based on packed cell volume during the culmination stage of development in $D$. discoideum (Thomas, 1979). This is some fivefold below the measured $K_{1}(0.1 \mathrm{~mm})$ of the $D$. discoideum enzyme for this intermediate. If compartmentalization is not a factor, then 6phosphogluconate may have a minimal effect in vivo on glucose-6-phosphate isomerase activity. However, the enzyme became more sensitive to 6-phosphogluconate when the $\mathrm{pH}$ of the assay was lowered to $7 \cdot 0$. The $\mathrm{pH}$ effect has been described previously and suggested as a possible control mechanism for modulation of isomerase activity (Geewater et al., 1965). Although direct measurement of intracellular $\mathrm{pH}$ has yet to be done in $D$. discoideum, it is interesting to note that the developmental medium for this organism is buffered in the acid range $(\mathrm{pH} \mathrm{6.5)}$.

The inhibition of glucose-6-phosphate isomerase by erythrose 4-phosphate and the high affinity of the enzyme for this intermediate suggests that it may function in a regulatory manner in carbohydrate metabolism. Under conditions where the metabolism of fructose 6-phosphate by the transketolase-transaldolase catalysed reactions (EC 2.2.1.1; sedoheptulose-7-phosphate:D-glyceraldehyde-3-phosphate glycolaldehydetransferase - EC 2.2.1.2; sedoheptulose-7-phosphate:D-glyceraldehyde-3-phosphate dihydroxyacetonetransferase) might lead to an accumulation of erythrose 4-phosphate, further formation would be prevented by inhibition of the isomerase step. On the other hand, it would appear that this reaction is close to equilibrium in vivo, based on the similarity of the mass action ratios $(0.32$ to 0.34$)$ to the equilibrium constant $(0.36)$ throughout differentiation (Thomas, 1979). However, in the absence of a dynamic model of this metabolic network, it is difficult to assess the extent to which the equilibrium would be displaced if regulation by erythrose 4-phosphate did occur.

This investigation was supported by U.S. Public Health Service grant no. AG00649 to D.T. and National Institutes of Health on Aging grants no. AG00433 and AG00260 to B. E. Wright.

\section{REFERENCES}

Cleland, S. V. \& Coe, E. L. (1968). Activities of glycolytic enzymes during the early stages of differentiation in the cellular slime mold Dictyostelium discoideum. Biochimica et biophysica acta 156, 44-50.
Cooper, J., Srere, P. A., TABAchnick, M. \& RACKER, E. (1958). The oxidative pentose phosphate cycle. II. Quantitative determination of intermediates and enzymes. Archives of Biochemistry and Biophysics 74, 306-314. 
Geewater, D. M. J., Hanshaw, E. H., Martin, R. E. \& PARR, C. W. (1965). Some observations on the $\mathrm{pH}$-dependence of the inhibition of phosphoglucose isomerase by straight-chain analogues. Biochemical Journal 97, 12P.

Grazi, E., DeFlora, A. \& Pontremoli, S. (1960). The inhibition of phosphoglucose isomerase by D-erythrose-4-phosphate. Biochemical and Biophysical Research Communications 2, 121-125.

KLUNGSOYR, L. \& ENDERSEN, A. (1964). Intracellular pH effect upon phosphoglucose isomerase in $E$. coli. Biochimica et biophysica acta 92, 378-388.

MARShall, R., SARGENT, D. \& WRIGHT, B. E. (1970). Glycogen turnover in Dictyostelium discoideum. Biochemistry 9, 3087-3094.

Matsushima, K. \& Simpson, F. J. (1965). The ribosephosphate and glucosephosphate isomerase of Aerobacter aerogenes. Canadian Journal of Microbiology 11, 967-975.

Noltmann, E. A. (1966). Phosphoglucose isomerase. Methods in Enzymology 9, 557-565.

PARR, C. W. (1956). Inhibition of phosphoglucose isomerase. Nature, London 178, 1401-1402.

Roe, J. M. \& Papadopoulos, N. M. (1954). The determination of fructose-6-phosphate and fructose1,6-diphosphate. Journal of Biological Chemistry 210, 703-707.
Salas, M., Vinuela, E. \& Sols, A. (1965). Spontaneous and enzymatically catalyzed anomerization of glucose 6-phosphate and anomeric specificity of related enzymes. Journal of Biological Chemistry 240, 561-572.

Saunders, S. A., Gracy, R. W., Schnazkerz, K. D. \& NoltmanN, E. A. (1969). Are honey-bees deficient in phosphomannose isomerase? Science 164, 858-859.

StaDTMAN, E. R. (1966). Allosteric regulation of enzyme activity. Advances in Enzymology 28, 41-72.

TAKedA, Y., HizukuRI, S. \& NikuNI, Z. (1967). Crystallization and properties of pea glucosephosphate isomerase. Biochimica et biophysica acta 146, 568-575.

Thомas, D. A. (1979). Pentose phosphate metabolism during differentiation in Dictyostelium discoideum. Journal of General Microbiology 113, 357-368.

Venkataraman, R. \& RACKER, E. (1961). Mechanism of action of transaldolase. Journal of Biological Chemistry 236, 1876-1887.

ZALITIS, J. \& OliveR, L. T. (1967). Inhibition of glucose phosphate isomerase by metabolic intermediates of fructose. Biochemical Journal 102, 753-759. 